Tina Božiković, mag. praesc. educ.

alumna Filozofskog fakulteta Sveučilišta u Splitu

Odsjek za rani i predškolski odgoj i obrazovanje

tbozikovic@ffst.hr

izv. prof. dr. sc. Ina Reić Ercegovac

Filozofski fakultet Sveučilišta u Splitu

Katedra za psihologiju

inareic@ffst.hr

dr. sc. Katija Kalebić Jakupčević, spec. klin. psih.

Filozofski fakultet Sveučilišta u Splitu

Katedra za psihologiju

kkalebicjakupcevic@ffst.hr

\title{
DOPRINOS TEMPERAMENTA I RODITELJSKOG PONAŠANJA RAZVOJNIM ISHODIMA DJECE PREDŠKOLSKE DOBI
}

Sažetak: Cilj ovoga istraživanja bio je ispitati pridonose li dimenzije roditeljskog ponašajnog stila objašnjenju razvojnih obilježja djece predškolske dobi i povrh dječjih temperamentalnih značajki. U istraživanju su sudjelovala 194 roditelja jednog djeteta predškolske dobi, od čega 95.36\% majki. Primijenjeni su Upitnik temperamenta EASI, Multidimenzijski upitnik roditeljstva i Upitnik za procjenu razvoja djeteta predškolske dobi. Rezultati su uputili na značajnu povezanost između dimenzija temperamenta prema modelu EASI (emocionalnost, aktivnost, socijabilnost $i$ impulzivnost), funkcionalnih razvojnih obilježja djeteta $i$ nekih dimenzija roditeljstva. Nisu utvrđene znatne razlike u procjenama temperamentalnih obilježja i razvojnih ishoda između dječaka i djevojčica. Rezultati regresijskih analiza pokazali su da je procjenama temperamentalnih dimenzija moguće objasniti visokih $56 \%$ - $74 \%$ varijance razvojnih ishoda djece predškolske dobi, ali i da dimenzije roditeljskog ponašanja dodatno ne pridonose objašnjenju varijance razvojnih obilježja djece uz kontrolu temperamenta. Uz ograničenja provedenog istraživanja, rezultati su interpretirani u kontekstu postojećih spoznaja o utjecajima na razvojne ishode djece predškolske dobi s posebnim naglaskom na važnost prepoznavanja $i$ razumijevanja temperamenta kao važne odrednice razvoja u dječjoj dobi.

Ključne riječi: dijete predškolske dobi, razvojna obilježja, roditeljsko ponašanje, temperament 


\section{UVOD}

Temperament predstavlja specifičnost svakog djeteta te određuje dječju emocionalnu ekspresivnost i spremnost odgovaranja na podražaje iz okoline. Pojedine dimenzije temperamenta dijelom uvjetuju i način odgoja djeteta, odnosno dinami$\mathrm{ku}$ roditeljskog ponašanja i reakcije okoline. Djeca su rođena s određenim temperamentom, kao i s osobinama koje su biološki uvjetovane. Budući da djetetova ličnost još ne uključuje brojne komponente koje postaju vidljive tek kasnije, poput uvjerenja, vrijednosti i stavova, njezino proučavanje ograničeno je na proučavanje izražavanja emocija i reakcija na podražaje iz okoline, odnosno na temperament. Vasta i sur. (1997) navode da je temperament sklop bihevioralnih dispozicija koje čine karakterističan način na koji osoba izražava svoje emocije i raspoloženja te opisuje djetetov ponašajni stil, daje odgovor na pitanje kako dijete nešto čini ne odražavajući pritom što čini.

Prema modelu Rothbart i suradnika (Rothbart i Derryberry, 1981; Rothbart i Putnam, 2002), sastavnice dječjeg temperamenta u ranoj i predškolskoj dobi oblikuju djetetovu ličnost, a među najvažnijima izdvajaju pozitivnu emocionalnost (smiješak na različite ugodne podražaje, uzbuđenje i uživanje), negativnu emocionalnost (nezadovoljstvo, frustriranost, neutješnost) i svjesnu kontrolu ponašanja (susprezanje, planirano ponašanje, usmjeravanje i održavanje pažnje) (Starc i sur. 2004). Tatalović Vorkapić i Žagar (2017) temperament povezuju s kombinacijom dinamičnih konstrukcija i procesa učenja te je, baš kao i dinamični sustav različitih čimbenika, osjetljiv na utjecaj sudionika koji manifestiraju različite osobine ličnosti i kontekstualne uvjete. Slično tome, Brezinšćak i Roje (2018) navode kako nasljeđe ne određuje cjelokupnu djetetovu ličnost, već veći dio karakteristika koje se onda razvijaju pod utjecajem okoline $\mathrm{i}$ to najviše roditelja.

Navodeći iskustva roditelja, Pernar (2010) smatra kako je netočna mitska tvrdnja prema kojoj je nevažna priroda djeteta, njegov urođeni temperament i ostale značajke. Ova autorica objašnjava kako postoji slaganje roditelja i stručnjaka u činjenici da su neka djeca rođena s izuzetno teškim temperamentom, a ostala su sasvim laka i kooperativna. Jasno je da takve dispozicije uvjetuju i način odgoja djeteta, reakcije okoline i dinamiku roditeljstva, što u konačnici dovodi do individualnih razlika u značajkama osobnosti i ponašanjima svakog djeteta i kasnije odraslog pojedinca.

Prema Starc i sur. (2004), dijete lakog temperamenta pokazuje pozitivne emocije i dugu perzistenciju, manje je strašljivo i posjeduje umjerenu razinu aktivnosti. Takvo dijete pruža roditelju osjećaj roditeljske kompetencije i tople emocionalne privrženosti. Dijete teškog temperamenta pokazuje malo pozitivnih emocija smiješkom, kratku perzistenciju, veliku strašljivost i razinu aktivnosti te kod roditelja otežava osjećaj roditeljske kompetencije, što rezultira osjećajem straha, napetosti i prevelike odgovornosti. Dijete opreznog temperamenta sporo se prilagođava 
promjenama, te je uglavnom negativne emocionalnosti. No kao što roditelj oblikuje dijete, tako i dijete oblikuje svoje roditelje. Sindik i Basta-Frljić (2008) zaključuju kako roditelji mogu pomoći djetetu razumjeti njegov temperament, odnosno kako on utječe na njegove osjećaje i ponašanje. Pritom je, smatra Pernar (2010), potrebno istaknuti da pri korigiranju dječjeg ponašanja roditelji komentiraju samo određeno ponašanje s kojim se ne slažu, a ne cjelokupnu djetetovu ličnost zbog toga što je davanje negativnih epiteta i generalizacija pogubno za doživljaj samoga sebe te je kao takvo izravan udar na osobnost. Također, i odgojitelji i roditelji trebali bi razumjeti djetetov temperament $i$ tomu prilagoditi vlastite reakcije na svako pojedino dijete imajući pritom na umu da svojim ponašanjem i stavovima utječu na rast i razvoj djece.

Teorijski okvir za ovo istraživanje čini model temperamenta koji su razvili Buss i Plomin $(1975,1984)$. Riječ je o razvojnom, multidimenzijskom modelu EASI prema kojem temperament uključuje četiri temeljne dimenzije - emocionalnost, aktivnost, socijabilnost i impulzivnost. U kasnijim je revizijama modela dimenzija impulzivnosti izostavljena jer nije dobila empirijsku potvrdu s obzirom na stabilnost i nasljednost. Emocionalnost se odnosi na intenzitet i kvalitetu emocionalnih reakcija, odnosno pokazuje koliko brzo dijete postaje uzbuđeno i počinje negativno reagirati na podražaje iz okoline. U početku života emocionalnost je moguće procijeniti brzinom reakcije na, primjerice, zvučni podražaj nakon kojeg slijedi manifestacija neugodnih emocija u vidu plakanja. Tijekom prve godine života emocionalnost se razvija prema reakcijama straha ili srdžbe, a uvelike ovisi o djetetovu iskustvu. Aktivnost predstavlja način djetetova korištenja energije, a uključuje tempo, intenzivne reakcije, izdržljivost i motivaciju. Djeca procijenjena visoko na ovoj dimenziji stalno su u pokretu te su usmjerena na istraživanje novih mjesta i aktivnosti. Socijabilnost se odnosi na djetetove sklonosti druženju i provođenju vremena s drugim ljudima; djeca procijenjena visoko na ovoj dimenziji ne vole biti sama i često potiču interakciju s drugima (Vasta i sur., 1997).

\section{RODITELJSTVO}

Roditeljstvo je pojam koji se odnosi na čitav niz procesa te se događa unutar karakterističnog prostora i vremena. Klarin (2006) napominje kako složenost okolinskih utjecaja, opasnost i nesigurnost u svakodnevnom životu, čine ulogu roditelja sve složenijom. Dok su se istraživači uglavnom usmjeravali na proučavanje utjecaja majke na dijete, suvremena literatura upućuje na to da upravo ravnopravna podjela roditeljskih dužnosti pogoduje pozitivnom doživljaju roditeljstva u oboma roditeljima (Buljan i sur., 2018). Štoviše, isti autori upućuju na to kako suvremeni pogled na roditeljstvo odgoj smatra uzajamnim procesom između roditelja i djeteta. Ljubetić i sur. (2019) navode roditelje kao prve djetetove učitelje koji dijete usmjeruju u njegovu emocionalnom i socijalnom razvoju te naglašavaju kako roditelji imaju najvažniju ulogu u djetetovu razvoju, a svojim djelovanjem utječu na 
djetetov kognitivni, psihički, fizički, socijalni, emocionalni i moralni razvoj. Šimić i Ljubetić (2018) ističu utjecaj pozitivne psihološke prilagodbe roditelja njihovoj ulozi koja povećava cjelokupno samopouzdanje te osjećaj sposobnosti za obavljanje roditeljske uloge, time i uspostavljanje sigurne emocionalne privrženosti s djetetom. Pored toga, kvalitetno obavljanje obiteljske funkcije, unutar stabilne obiteljske strukture, ključno je za održavanje funkcije i strukture obitelji, ali je ključno i za održavanje cjelovitog i zdravog razvoja svih pojedinaca unutar obiteljske zajednice, kao i cjelokupnog društva (Ljubetić i Batinica, 2015). Dok u traganju za zadovoljavajućim odgovorima u roditeljstvu roditelji biraju različite filozofije odgoja, Ljubetić (2011) navodi kako se dio roditelja okreće religiji, neki vlastitoj intuiciji, ostali se prisjećaju ponašanja svojih roditelja te ih nastoje primijeniti i/ili prilagoditi.

Roditeljski odgojni stil predstavlja opće ozračje u kojem se odvija niz interakcija između roditelja i djeteta. Postoji nekoliko različith tipologija roditeljskih stilova, a jedna od najzastupljenijih ona je koju je definirala Diana Baumrind (1967) koja zaključuje da su roditeljski nadzor, ljubav i toplina najvažniji elementi roditeljske funkcije te je prema tome definirala četiri različita roditeljska stila: autoritaran, autoritativan, permisivan i zanemarujući (Obradović i Čudina-Obradović, 2003, str. 269). Roditeljska toplina odnosi se na potporu, brigu i ohrabrivanje djeteta, a roditeljska je kontrola obilježena željom roditelja da upravlja djetetovim životom, kontrolira djetetovo ponašanje kažnjavanjem, snagom i deprivacijom (Klarin, 2006). Drugu klasifikaciju odgojnog stila nudi Rohnerov model roditeljstva (1986), koji se temelji na dimenzijskom pristupu, pri čemu je ključna dimenzija roditeljskog prihvaćanja na čijem je jednom polu roditeljsko odbijanje, a na drugome prihvaćanje. Na osnovi tog modela Rohner (1986) pokušao je predvidjeti posljedice roditeljskog odbijanja i prihvaćanja na ponašanje djeteta, na njegov kognitivni i emocionalni razvoj te na cjelokupno funkcioniranje $\mathrm{u}$ odrasloj dobi. Naime, s obzirom na prisutnost ili odsutnost roditeljske topline ili prihvaćanja, ovaj autor razlikuje dva tipa roditelja. Dok jedan tip roditelja prihvaća svoje dijete te ga fizički i verbalno podupire, drugi tip roditelja odbija dijete pokazujući neprijateljstvo i ljutnju prema njemu. Sukladno tomu Klarin (2006) ističe kako djeca koja odnos roditelja percipiraju odbijajućim u većoj mjeri pokazuju agresivna ponašanja i neprijateljstvo prema drugima. U svakom slučaju sasvim je jasno da su roditeljska toplina i potpora poželjni u odgoju, a odbijanje i zanemarivanje nepoželjni su i kao takvi mogu imati negativne posljedice za razvoj djeteta.

Unutar integrativnog modela roditeljstva, koji se sastoji od subjektivnog doživljaja roditeljstva, roditeljskog ponašanja i postupaka te odgojnog stila, Obradović i Čudina Obradović (2003) ističu utjecaje na roditeljstvo poput značajki roditelja (osobnost i spol, emocionalna zrelost, psihološko zdravlje, znanje i dr.), značajki djeteta (spol, dob, temperament, sposobnosti i dr.) te šireg društvenog $\mathrm{i}$ obiteljskog konteksta (struktura obitelji, ekonomska sigurnost, bračna potpora i sl.). Naime, 
svako dijete kod skrbnika pobuđuje reakcije koje su u skladu s roditeljskom percepcijom i djetetovim temperamentom. Stupanj podudaranja roditeljskog odgojnog utjecaja i djetetova temperamenta podrazumijeva stvaranje odgojne okoline koja uvažava djetetov stil ponašanja uz istodobno poticanje adaptivnijeg funkcioniranja (Berk, 2008). Također, dječje karakteristike pridonose lakoći s kojom roditelji mogu primjenjivati autoritativni odgojni stil. Prema tome, impulzivna i emocionalno negativna djeca vjerojatno će izazvati prisilno i nedosljedno discipliniranje (Berk, 2015).

Bowlby (1988, prema Reić Ercegovac i Ljubetić, 2019) objašnjava kako privrženost iz ranog djetinjstva na temelju koje pojedinac stvara unutarnje radne modele oblikuje roditeljski odgojni stil, čime je istaknuto kako sigurna privrženost ima važnu ulogu u kontekstu međugeneracijskog prijenosa roditeljskog doživljaja i ponašanja. Iste autorice naglašavaju važnost usredotočene svjesnosti u roditeljstvu (engl. mindful parenting) koja proizlazi iz namjernog usmjeravanja pažnje na aktualni trenutak interakcije roditelj-dijete bez osuđivanja. Roditelji koji osvještavaju djetetove trenutačne potrebe i pritom ih prihvaćaju mogu stvoriti podržavajući odgojni kontekst čime ostvaruju kvalitetnu interakciju s djetetom i više zadovoljstva. Dimenzije koje se odnose na dijete, objašnjavaju ove autorice, uključuju pažnju usmjerenu na aktualni trenutak, empatiju i prihvaćanje djeteta. Ljubetić (2011) svjesno roditeljstvo promatra kao krajnji cilj, odnosno imperativ odgovornog roditeljstva čija je bit preuzimanje potpune odgovornosti obaju roditelja kako bi odgojili zdravo, inteligentno i sretno dijete.

Roditeljska kompetencija predstavlja kontinuum od pedagoške nekompetencije do pedagoške kompetencije koji uključuje funkcionalna i disfunkcionalna odgojna djelovanja (Ljubetić, 2012). Autorica navodi da ,pedagoški kompetentan roditelj svakodnevno i višekratno mora ‘aktivirati` sve komponente svoje roditeljske meta-kompetencije jer u protivnom nije u mogućnosti uspješno odgovoriti svojoj roditeljskoj ulozi” (Ljubetić, 2012, str. 26). Prema Obradović i Čudina Obradović (2003), doživljaj roditeljstva i osjećaj roditeljske kompetencije značajno utječu na djetetove karakteristike. Autori ističu da novorođenčad i djeca u prvoj godini života, osim što mijenjaju doživljaj roditeljstva (zbog karakteristika vlastitog temperamenta), utječu na stvaranje emocionalnog ozračja izazivajući ponašanja i postupke roditelja koji mogu povoljno ili nepovoljno utjecati na cjelokupan djetetov razvoj. Svaki odgojni postupak roditelja u svojoj osnovi sadrži ciljeve i vrijednosti definirane razvojnim rezultatima koji se žele postići. Kako će dijete prihvatiti roditeljske aktivnosti i postupke, određeno je utjecajem ciljeva i vrijednosti, te ih autori definiraju kao kontekst, ozračje u kojem dijete percipira, interpretira i prihvaća različite roditeljske postupke. 


\section{RAZVOJ DJECE U RANOJ I PREDŠKOLSKOJ DOBI}

Pod pojmom razvoj razumijevamo slijed promjena u osobinama, sposobnostima i ponašanju djeteta zbog kojih se ono mijenja te postaje sve veće, spretnije, sposobnije, društvenije, prilagodljivije itd. (Starc i sur., 2004). Razvoj je dinamičan proces koji se odvija predvidljivim koracima unutar socijalnog konteksta. Roje i Buljan Flander (2018) napominju kako je za podržavanje razvoja nužno pratiti dijete te mu pružiti optimalne izazove, dovoljno teške, ali i dovoljno lagane, da ih dijete može ostvariti samostalno ili uz pomoć kompetentnog vršnjaka odnosno odrasle osobe.

Mnogi autori smatraju emocionalni razvoj jednim od najvažnijih procesa $u$ razvoju ličnosti koji ujedno predstavlja rezultat međusobnog utjecaja bioloških značajki pojedinca i njegova socijalnog učenja (Bašić i sur., 2005). Emocionalni razvoj započinje rođenjem i to razlikovanjem ugode od neugode iz čega se kasnije tijekom razvoja diferenciraju različite pozitivne ili negativne emocije (Berk, 2008), primjerice uznemirenost, gnjev, ljubomora, gađenje i strah odnosno zadovoljstvo, radost, oduševljenje i naklonost prema drugima. Autori ističu kako je emocionalni razvoj djeteta ishod njegovih potreba koje su u ranoj dobi posebno naglašene fiziološkim, psihičkim i socijalnim potrebama te ih dijete može zadovoljiti interakcijom s drugim ljudima i to ponajprije u obitelji. Štoviše, negativne će se emocije rjeđe javljati te će izgubiti intenzitet ako se njeguju pozitivne emocije pri čemu se izgrađuje pozitivna slika o sebi.

Buljan Flander i Ćorić Špoljar (2018) naglašavaju potrebu za svakodnevnim malim frustracijama kako bi se djeca emocionalno razvijala opisujući te situacije kao dragocjene i vrijedne prilike za učenje. Poznavanje dječjeg emocionalnog stanja omogućuje nam razumjeti dijete, imati realistična očekivanja od njega i učinkovitije se nositi s njegovim ponašanjem (Brezinšćak i Roje, 2018, str. 48). Također, ovi autori navode kako će sva djeca doživljavati sve emocije, no o njihovu temperamentu ovisi koje će emocije dijete doživljavati češće i intenzivnije. Proces učenja vještina suočavanja s emocijama pod utjecajem je sazrijevanja živčanog sustava koji, napominju autorice, pruža temelje potrebne za kontrolu emocija, djetetova temperamenta i roditeljske podrške. Bitno je potaknuti dijete na vješto upravljanje emocijama, odnosno pomoći mu pronaći konstruktivan i prihvatljiv način što je sastavni dio samoregulacije emocija koja počinje u ranom djetinjstvu, ali se razvija i usavršava tijekom većeg dijela života. Samoregulacija emocija, kao jedan od važnih elemenata emocionalne inteligencije, ovisi i o naslijeđenim dispozicijama, ali i o okolinskim čimbenicima gdje roditelji svakako imaju najznačajniju ulogu.

Socijalni razvoj usko je povezan s emocionalnim razvojem te se ogleda u usvajanju socijalnog ponašanja potrebnog za prilagođavanje drugima i društvu. Već od rane dobi socijalna interakcija djeluje u sklopu nasljednih i stečenih dispozicija te dijete u tom procesu nije pasivno, već je aktivno (Bašić i sur., 2005). 
Socijalno su kompetentna djeca ona koja se upuštaju u zadovoljavajuće interakcije s odraslima i s ostalom djecom unaprjeđujući takvim interakcijama osobnu kompetenciju. Na razvoj socijalne kompetencije utječe niz čimbenika iz mikrosustava, a to su obitelj, vršnjaci, odgojitelji, učitelji i sl. (Katz i McClellan, 2005). Ti autori navode regulaciju emocija, socijalna znanja i razumijevanje, socijalna umijeća i socijalne dispozicije kao važne sastavnice socijalne kompetencije. Smatraju kako su socijalna umijeća najvažnija za socijalno sudjelovanje i uspjeh te da djeca s razvijenim vještinama socijalne kompetencije usklađuju svoje ponašanje s tuđim, razmjenjuju informacije i ispituju sličnosti i razlike. Katz i McClellan (2005) ističu i probleme socijalizacije (stidljivost, niska razina interakcije, agresivnost i usamljenost), koji su prisutni kod djece koja još nisu postigla dovoljnu kontrolu poriva ili kod djece kojima nedostaje znanja i umijeća potrebnih za uključivanje u vršnjačke interakcije.

Važan je aspekt djetetova razvoja motorički razvoj koji prati vremenski slijed pri čemu dijete postupno iskazuje sve složenije sposobnosti pokreta (Štimac i Božić Knež, 2018). Djetetov motorički razvoj očituje se u sve većoj sposobnosti svrhovitog i skladnog korištenja tijela pri čemu je za normalan psihomotorni razvoj potrebno iskustvo (Bašić i sur., 2005). Autori napominju kako je za djetetov motorički razvoj važan i njegov mentalni razvoj s obzirom na to da ga znatiželja i zainteresiranost navode na istraživanje svijeta koji ga okružuje. Ipak, o stupnju i tempu motoričkog razvoja među djecom iste kronološke dobi mogu biti uočljive interindividualne razlike koje su uvjetovane nasljednim i okolinskim čimbenicima. Također, pomaci u motoričkom razvoju nastaju spontano, zbog sazrijevanja živčanog i mišićno-koštanog sustava te razvojem osjeta i percepcije. Djetetu je potrebno omogućiti dovoljno prilika kako bi ono upoznalo fizičku okolinu i otkrilo radost kretanja (Starc i sur., 2004).

Spoznajni se razvoj odnosi na mentalne procese kojima dijete pokušava razumjeti svijet oko sebe te se događa postupnim ovladavanjem pojmovima i misaonim operacijama (Slunjski, 2012). Iznimno je važno osigurati uvjete za razvoj pozornosti i kognitivnih strategija djeteta, kao i kontinuitet iskustva. Slunjski (2001) naglašava kako je potrebno dobro poznavati individualne potrebe, sklonosti i potencijale djeteta te u skladu s njima poticati i podržavati njegovo samostalno učenje. U djetetove misaone, odnosno kognitivne sposobnosti, ubrajamo pamćenje, učenje, pažnju, mišljenje, vještine rješavanja problema, sposobnost učenja i rasuđivanja te donošenje odluka (Roje i Buljan Flander, 2018).

Iz svega navedenoga očito je kako je djetetov razvoj složen proces u kojem se utjecaji djetetova biološkog nasljeđa, okoline i iskustava isprepliću i usmjeravaju razvoj. Više je čimbenika koji mogu biti presudni za djetetove razvojne ishode na pojedinom stupnju razvoja, stoga se u ovom istraživanju željelo provjeriti pridonose li roditeljska ponašanja objašnjenju djetetovih mogućnosti na određenom stupnju razvoja i povrh temperamentalnih značajki koje predstavljaju djetetove 
biološke dispozicije. Naime, iako istraživanja upućuju na važnu ulogu roditeljskih ponašanja za različite razvojne ishode djece, primjerice internalizirane/eksternalizirane poteškoće (Parent i sur., 2016), istraživanja rijetko uzimaju u obzir specifičnosti temperamenta djeteta kao čimbenika o kojem ovisi i roditeljsko ponašanje i njegov utjecaj na djetetov razvoj.

Kako bi se ostvario navedeni cilj istraživanja, pokušalo se odgovoriti na sljedeće probleme istraživanja: 1 . ispitati povezanost između sociodemografskih obilježja roditelja i njihovih procjena roditeljskog ponašanja; 2. ispitati postoje li razlike u roditeljskim ponašanjima, roditeljskoj procjeni dječjeg temperamenta i roditeljskoj procjeni razvojnih značajki s obzirom na spol djeteta; 3 . ispitati povezanost između temperamentalnih značajki djeteta i razvojnih ishoda djece predškolske dobi; 4. ispitati pridonose li dimenzije roditeljskog ponašanja i temperamenta djetetovim razvojnim značajkama.

\section{METODA ISTRAŽIVANJA}

\section{UZORAK}

U istraživanju je sudjelovao prigodan uzorak od 194 roditelja djece predškolske dobi od čega $95.36 \%$ majki. S obzirom na dob, u uzorku je bilo $3.61 \%$ (N $=7$ ) roditelja u najmlađoj (18 - 25 godina) i najstarijoj skupini (više od 46 godina), $59.28 \%$ roditelja $(\mathrm{N}=115)$ u dobi od 26 do 35 godina te $33.51 \%(\mathrm{~N}=65)$ roditelja u dobi od 36 do 45 godina. Prema stupnju obrazovanja, najveći je udio visokoobrazovanih roditelja $(\mathrm{N}=78 ; 40.21 \%)$, potom roditelja sa srednjom stručnom spremom $(\mathrm{N}=70 ; 36.08 \%)$ te roditelja s višom ili prvostupničkom razinom obrazovanja $(\mathrm{N}=46 ; 23.71 \%)$.

\section{INSTRUMENTI ISTRAŽIVANJA}

Upitnikom općih podataka prikupljeni su podatci o dobi, spolu i razini obrazovanja roditelja trima pitanjima zatvorenog tipa te podatak o djetetovu spolu. Multidimenzijski upitnik roditeljstva, MAPS (The Multidimensional Assessment of Parenting Scale, Parent i Forehand, 2017) korišten je za ispitivanje dviju domena roditeljstva: pozitivno roditeljstvo (četiri faktora: toplina - primjerice Pokazujem djetetu ljubav tako da ga zagrlim, poljubim ili držim na rukama, podrška - primjerice Poštujem djetetovo mišljenje i potičem ga da ga izrazi, pozitivno potkrjepljenje - primjerice Ako od djeteta što tražim i ono to učini, pohvalim ga što me poslušalo, i proaktivno roditeljsko ponašanje - primjerice Objasnim djetetu zašto ga discipliniram zbog ružnog ponašanja) te negativno roditeljstvo (tri faktora: hostilnost - primjerice Vičem i derem se kada se moje dijete ružno ponaša, permisivnost - primjerice Puštam dijete iz kazne ranije nego sam prvotno rekao/-la, i fizička kontrola - primjerice Kada sam izrazito ljut/-a, pljusnem dijete). Upitnik 
je za potrebe istraživanja preveden s engleskog jezika na hrvatski jezik korištenjem standardnog postupka povratnog prijevoda kako bi se osigurala njegova usporedivost s izvornikom (Hui i Triandis, 1985; Van de Vijver i Hambleton, 1996). Upitnik se sastoji od 34 čestice, a zadatak je sudionika istraživanja procijeniti koliko često su se ponašali na opisani način u posljednja dva mjeseca na ljestvici od 1 do 5 (gdje 1 znači nikada, 5 uvijek). Budući da je provjera pouzdanosti po pojedinim faktorima uputila na nisku pouzdanost na dvjema podljestvicama, toplini i podršci, provedena je konfirmacijska faktorska analiza na šest faktora pri čemu su svi faktori jednaki kao u izvorniku upitnika (Parent i Forehand, 2017), osim što su čestice koje se odnose na toplinu i podršku tretirane kao jedan faktor. Rezultati CFA uputili su na zadovoljavajuće pristajanje podataka u ovom istraživanju modelu sa šest faktora (RMSEA $=.07$; hi-kvadrat $/ \mathrm{df}=2.22)$ pa je formirano šest ukupnih rezultata, po tri za dvije široke domene roditeljstva (pozitivno/negativno) zbrajanjem odgovora na česticama koje su činile pojedine faktore. Deskriptivni pokazatelji podljestvica prikazani su u Tablici 1 .

Tablica 1. Deskriptivni pokazatelji podljestvica roditeljskog ponašanja

\begin{tabular}{lcccccc}
\hline & M (SD) & $\begin{array}{c}\text { Broj } \\
\text { čestica }\end{array}$ & Cronbach $\alpha$ & Raspon & Asimetričnost & Spljoštenost \\
\hline Toplina & $\begin{array}{c}28.50 \\
(1.96)\end{array}$ & 6 & .68 & $20-30$ & -1.56 & 2.33 \\
$\begin{array}{l}\text { Pozitivno } \\
\text { potkrjepljenje }\end{array}$ & $\begin{array}{c}18.81 \\
(1.74)\end{array}$ & 4 & .65 & $12-20$ & -2.00 & 4.26 \\
$\begin{array}{l}\text { Proaktivno } \\
\text { ponašanje }\end{array}$ & $\begin{array}{l}25.34 \\
(3.12)\end{array}$ & 6 & .63 & $16-30$ & -.62 & .07 \\
Hostilnost & 14.33 & 7 & .65 & $6-23$ & .21 & -.26 \\
$\begin{array}{l}\text { Permisivnost } \\
(3.48)\end{array}$ & $\begin{array}{l}16.66 \\
(4.90)\end{array}$ & 7 & .77 & $8-31$ & .52 & -.07 \\
$\begin{array}{l}\text { Fizička } \\
\text { kontrola }\end{array}$ & $\begin{array}{l}5.70 \\
(2.41)\end{array}$ & 4 & .83 & $4-15$ & 1.59 & 2.04 \\
\hline
\end{tabular}

Upitnik temperamenta EASI (Instrument of Child Temperament, Buss i Plomin, 1975, prema Sindik i Basta Frljić, 2008) korišten je za procjenu četiriju dimenzija djetetova temperamenta - emocionalnost (primjerice Lako se uplaši), aktivnost (primjerice Stalno je u pokretu), socijabilnost (primjerice Radije se igra samo nego s drugima) te impulzivnost (primjerice Uigri brzo izmjenjuje igračke). Upitnik primijenjen u ovom istraživanju sastojao se od 20 čestica pri čemu su sudionici procjenjivali odgovara li opisani način ponašanja njihovu djetetu na ljestvici od 1 do 5 ( 1 - uopće ne, 5 - u potpunosti da). U ranijim primjenama utvrđena je zadovoljavajuća pouzdanost tipa unutarnje konzistencije te test-retest pouzdanost (Matthiesen i Tambs, 1999; Sindik i Basta Frljić, 2008). S obzirom na teorijski 
model, empirijske primjene te zadovoljavajuće koeficijente pouzdanosti, formirana su četiri ukupna rezultata kao sume procjena na česticama koje čine pojedinu dimenziju. Treba napomenuti da je iz podljestvica emocionalnosti, aktivnosti i impulzivnosti izostavljena po jedna čestica u odnosu na inačicu primijenjenu u ovom istraživanju (Sindik i Basta Frljić, 2008) zbog niže pouzdanosti. Deskriptivni pokazatelji podljestvica prikazani su u Tablici 2.

Tablica 2. Deskriptivni pokazatelji podljestvica dječjeg temperamenta

\begin{tabular}{lcccccc}
\hline & $\begin{array}{c}\mathrm{M} \\
(\mathrm{SD})\end{array}$ & $\begin{array}{c}\text { Broj } \\
\text { čestica }\end{array}$ & Cronbach $\alpha$ & Raspon & Asimetričnost & Spljoštenost \\
\hline Emocionalnost & $\begin{array}{l}10.87 \\
(3.74)\end{array}$ & 4 & .67 & $4-19$ & .02 & -.74 \\
Aktivnost & $\begin{array}{l}12.90 \\
(3.75)\end{array}$ & 4 & .57 & $4-20$ & -.11 & -.66 \\
Socijabilnost & $\begin{array}{l}17.85 \\
(6.09)\end{array}$ & 5 & .88 & $5-25$ & -.67 & -.89 \\
Impulzivnost & $\begin{array}{l}11.19 \\
(3.94)\end{array}$ & 4 & .75 & $4-20$ & .13 & -.67 \\
\hline
\end{tabular}

Upitnik za procjenu razvoja djeteta predškolske dobi korišten je za procjenu razvojnih obilježja djeteta, a sastoji se od 37 pitanja koja se odnose na različita područja razvoja (govor - primjerice Točno prepričava priču iz slikovnice, finu motoriku - Boji unutar zadane linije, kognitivne sposobnosti - primjerice Razlikuje prošlost i budućnost u smislu važnijih događaja, samostalnost - primjerice Samostalno je prilikom jela, socioemocionalne kompetencije - primjerice Iskazuje empatiju, poteškoće - primjerice Nekontrolirano mokri). Roditelji su procjenjivali razvijenost svakog obilježja na ljestvici procjene od 1 do $5(1-$ uopće ne, 5 - u potpunosti da). Utvrđena je visoka pouzdanost svih podljestvica te su formirani rezultati po područjima razvoja čiji su deskriptivni pokazatelji prikazani u Tablici 3 .

Tablica 3. Deskriptivni pokazatelji podljestvica razvojnih značajki djeteta

\begin{tabular}{lcccccc}
\hline & M (SD) & $\begin{array}{c}\text { Broj } \\
\text { čestica }\end{array}$ & $\begin{array}{c}\text { Cronbach } \\
\alpha\end{array}$ & Raspon & Asimetričnost & Spljoštenost \\
\hline Govor & $18.71(7.41)$ & 5 & .96 & $5-25$ & -.93 & -.82 \\
Fina motorika & $16.82(5.69)$ & 5 & .78 & $5-25$ & -.63 & -.82 \\
Samostalnost & $11.31(4.47)$ & 3 & .96 & $3-15$ & -.93 & -.77 \\
$\begin{array}{l}\text { Kognitivne } \\
\text { sposobnosti }\end{array}$ & $17.72(7.08)$ & 5 & .94 & $5-25$ & -.68 & -1.07 \\
$\begin{array}{l}\text { Socioemocionalne } \\
\text { kompetencije }\end{array}$ & $25.73(9.42)$ & 7 & .95 & $7-35$ & -.86 & -.81 \\
Poteškoće & $27.42(17.11)$ & 12 & .96 & $12-60$ & .86 & -.91 \\
\hline
\end{tabular}




\section{POSTUPAK ISTRAŽIVANJA I ANALIZA PODATAKA}

Istraživanje je provedeno online u svibnju 2020. godine. U istraživanju su sudjelovali roditelji djece predškolske dobi iz više predškolskih ustanova Splitskodalmatinske županije. U kratkoj uputi bili su upoznati s ciljem provođenja istraživanja i načinom popunjavanja upitnika. Svim sudionicima naglašeno je da je istraživanje anonimno, da mu dobrovoljno pristupaju te da mogu slobodno odustati od sudjelovanja u bilo kojem trenutku. Budući da je većina varijabla imala parametre asimetričnosti i spljoštenosti $u$ rasponu od -2 do $+2, u$ analizi podataka korišteni su parametrijski postupci (Gravetter i Wallnau, 2014), a korišten je statistički program STATISTICA13.

\section{REZULTATI ISTRAŽIVANJA}

Kako bi se ispitalo postoji li povezanost između sociodemografskih obilježja roditelja i njihovih procjena roditeljskog ponašanja, izračunane su korelacije prikazane u Tablici 4.

Tablica 4. Povezanost između roditeljskih ponašanja i sociodemografskih obilježja roditelja

\begin{tabular}{lccc}
\hline & Spol roditelja & Dob roditelja & Razina obrazovanja \\
\hline Toplina & $.16^{*}$ & .09 & .05 \\
Pozitivno potkrjepljenje & .05 & .01 & .01 \\
Proaktivno roditeljsko ponašanje & $.18^{*}$ & -.07 & .12 \\
Permisivnost & $-.19^{*}$ & .09 & .06 \\
Hostilnost & -.01 & .07 & .01 \\
Fizička kontrola & -.05 & -.10 & -.04 \\
\hline
\end{tabular}

${ }^{*} \mathrm{p}<.05$

Značajna je povezanost utvrđena između spola roditelja i topline te permisivnosti, pri čemu su višu razinu topline i nižu razinu permisivnosti iskazale majke. Dob i razina obrazovanja roditelja nisu se pokazale povezanima niti s jednom varijablom roditeljskog ponašanja.

Tablica 5. Roditeljska ponašanja s obzirom na spol djeteta

\begin{tabular}{lccccc}
\hline & $\mathrm{M}_{\text {diečaci }}$ & $\mathrm{M}_{\text {dievö̌cice }}$ & $\mathrm{SD}_{\text {diěaci }}$ & $\mathrm{SD}_{\text {dievoičcice }}$ & $\mathrm{t}(\mathrm{df}=192)$ \\
\hline Toplina & 4.73 & 4.77 & .36 & .30 & -1.01 \\
Pozitivno potkrjepljenje & 4.73 & 4.68 & .44 & .43 & .78 \\
Proaktivno roditeljsko ponašanje & 4.25 & 4.20 & .51 & .53 & .75 \\
Permisivnost & 2.13 & 2.14 & .65 & .65 & -.05 \\
Hostilnost & 2.41 & 2.37 & .60 & .57 & .56 \\
Fizička kontrola & 1.47 & 1.38 & .63 & .58 & .97 \\
\hline
\end{tabular}


U Tablici 5 prikazani su rezultati $t$-testova kojima su uspoređena roditeljska ponašanja s obzirom na spol djeteta. Rezultati su pokazali kako nema razlike $u$ procjeni ijedne varijable roditeljskog ponašanja s obzirom na spol djeteta. Roditelji su jednako procijenili svoje roditeljsko postupanje bez obzira na to je li riječ o roditelju djevojčica ili dječaka.

Tablica 6. Usporedba roditeljskih procjena dječjeg temperamenta s obzirom na spol djeteta (rezultati $t$-testova)

\begin{tabular}{lrrrrc}
\hline & $\mathrm{M}_{\text {diečaci }}$ & $\mathrm{M}_{\text {dievoiëice }}$ & $\mathrm{SD}_{\text {diečaci }}$ & $\mathrm{SD}_{\text {dievojïice }}$ & $\mathrm{t}(\mathrm{df}=192)$ \\
\hline Emocionalnost & 2.73 & 2.71 & .95 & .92 & .19 \\
Aktivnost & 3.31 & 3.14 & .89 & .98 & 1.27 \\
Socijabilnost & 3.59 & 3.55 & 1.23 & 1.20 & .21 \\
Impulzivnost & 2.85 & 2.75 & .99 & .99 & .73 \\
\hline
\end{tabular}

Razlike u roditeljskoj procjeni dječjeg temperamenta s obzirom na spol djeteta prikazane su u Tablici 6 . Slično kao i kod procjena roditeljskog ponašanja, rezultati su pokazali kako su roditelji jednakim procijenili pojedine dimenzije temperamenta i kod dječaka i kod djevojčica.

Tablica 7. Usporedba roditeljskih procjena razvojnih značajki s obzirom na spol djeteta (rezultati $t$-testova)

\begin{tabular}{lccccc}
\hline & $\mathrm{M}_{\text {diečaci }}$ & $\mathrm{M}_{\text {dievoižcice }}$ & $\mathrm{SD}_{\text {diečaci }}$ & $\mathrm{SD}_{\text {dievoiëice }}$ & $\mathrm{t}(\mathrm{df}=192)$ \\
\hline Govor & 3.75 & 3.74 & 1.40 & 1.56 & .05 \\
Motorika & 3.26 & 3.47 & 1.08 & 1.18 & -1.32 \\
Samostalnost & 3.77 & 3.78 & 1.44 & 1.53 & -.03 \\
Kognitivne sposobnosti & 3.50 & 3.59 & 1.39 & 1.45 & -.45 \\
Socioemocionalne & 3.71 & 3.64 & 1.29 & 1.41 & .38 \\
kompetencije & & & & & \\
Razvojne poteškoće & 2.23 & 2.34 & 1.38 & 1.47 & -.05 \\
\hline
\end{tabular}

Kako bi se ispitalo razlikuju li se procjene roditelja o razvojnim značajkama djece s obzirom na spol djece, učinjeni su $t$-testovi te nisu utvrđene razlike, odnosno roditelji su jednakim procijenili razvijenost svih područja bez obzira na to je li riječ o dječacima ili djevojčicama (Tablica 7). 


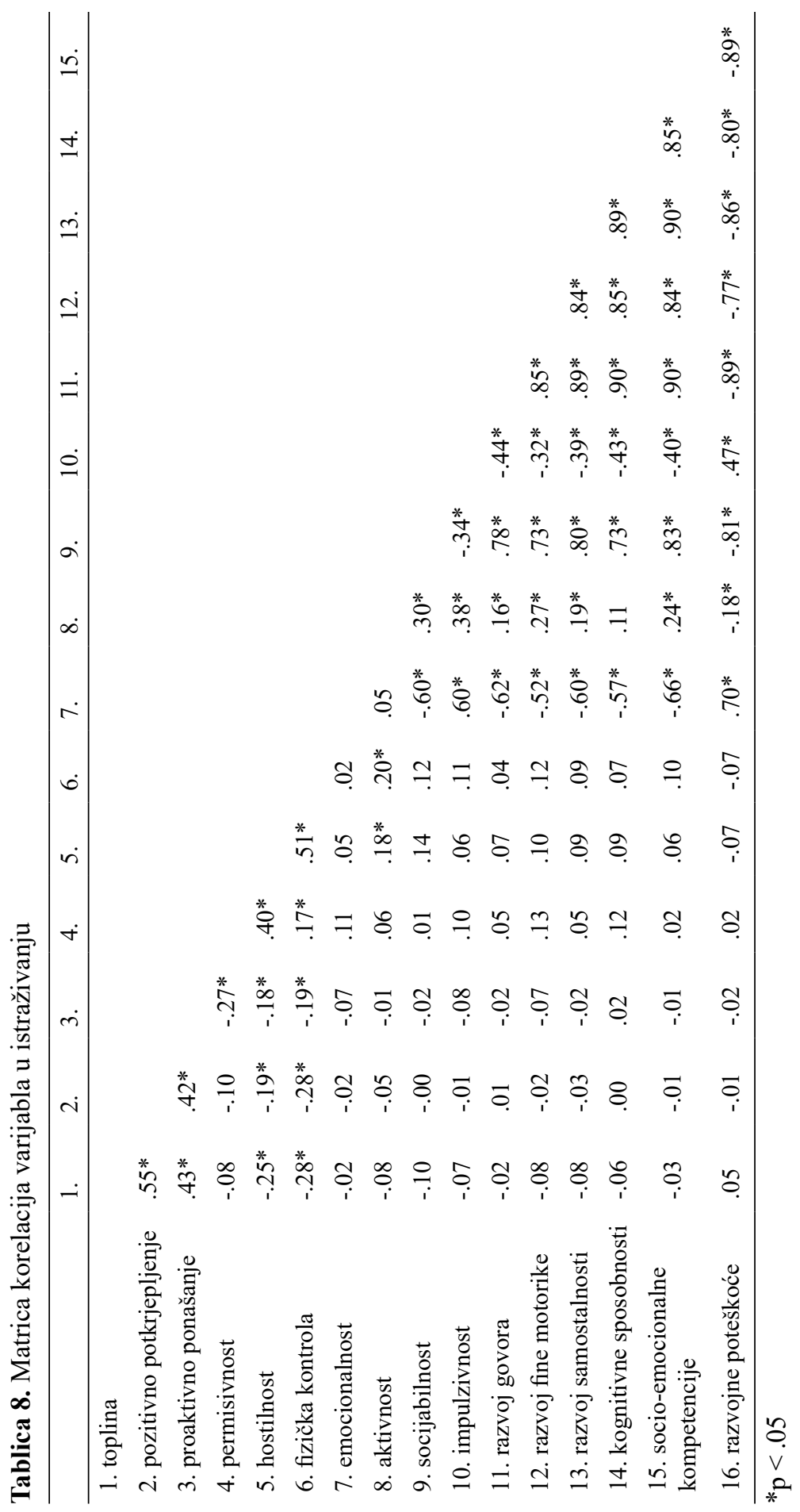


U Tablici 8 prikazana je matrica korelacija iz koje je vidljivo da je dimenzija aktivnosti temperamenta značajno povezana s hostilnosti roditelja i s fizičkom kontrolom. Dakle, roditelji koji su svoja ponašanja procijenili hostilnijima te češće upotrebljavaju fizičku kontrolu, ujedno su procijenili i višu razinu aktivnosti kao obilježja temperamenta djeteta. Nadalje, razvoj govora, fine motorike, samostalnosti, kognitivne sposobnosti i socioemocionalne kompetencije negativno su povezani s dimenzijom emocionalnosti, što upućuje na zaključak da su roditelji koji su djecu procijenili višim procjenama na dimenziji emocionalnosti kao obilježja temperamenta, ujedno su procijenili nižim djetetova razvojna postignuća u većini područja.

Tablica 9. Rezultati HRA s razvojnim obilježjima djeteta kao kriterijima

\begin{tabular}{|c|c|c|c|c|c|c|}
\hline & Govor & $\begin{array}{c}\text { Fina } \\
\text { motorika }\end{array}$ & Samostalnost & $\begin{array}{l}\text { Kognitivne } \\
\text { sposobnosti }\end{array}$ & $\begin{array}{l}\text { Socioemo- } \\
\text { cionalne } \\
\text { vještine }\end{array}$ & Poteškoće \\
\hline \multicolumn{7}{|c|}{ 1. korak - temperament } \\
\hline Emocionalnost & $-.15^{*}$ & -.11 & $-.13^{*}$ & -.11 & $-.22 *$ & $.26^{*}$ \\
\hline Aktivnost & .05 & $.15^{*}$ & .04 & .00 & .09 & -.08 \\
\hline Socijabilnost & $.62 *$ & $.58^{*}$ & $.67 *$ & $.62 *$ & $.64^{*}$ & $-.58^{*}$ \\
\hline Impulzivnost & $-.16^{*}$ & -.11 & -.11 & $-.15^{*}$ & -.08 & $.15^{*}$ \\
\hline $\mathrm{R}\left(\mathrm{R}^{2}\right)$ & $.81(.66)$ & $.75(.56)$ & $.81(.66)$ & $.76(.58)$ & $.86(.73)$ & $.86(.74)$ \\
\hline$F(d f)$ & $\begin{array}{l}91.46^{*} \\
(4.189)\end{array}$ & $\begin{array}{l}59.90^{*} \\
(4.189)\end{array}$ & $\begin{array}{l}91.75^{*} \\
(4.189)\end{array}$ & $\begin{array}{l}64.53^{*} \\
(4.189)\end{array}$ & $\begin{array}{l}130.0^{*} \\
(4.189)\end{array}$ & $\begin{array}{l}131.93^{*} \\
(4.189)\end{array}$ \\
\hline \multicolumn{7}{|c|}{ 2. korak - roditeljska ponašanja } \\
\hline Emocionalnost & $-.16^{*}$ & -.12 & $-.13^{*}$ & -.12 & $-.22^{*}$ & $.26^{*}$ \\
\hline Aktivnost & .06 & $.16^{*}$ & .04 & .00 & $.10^{*}$ & -.08 \\
\hline Socijabilnost & $.62^{*}$ & $.57^{*}$ & $.67^{*}$ & $.60 *$ & $.65^{*}$ & $-.58^{*}$ \\
\hline Impulzivnost & $-.17 *$ & -.13 & -.11 & $-.16^{*}$ & -.09 & $.16^{*}$ \\
\hline Toplina & .04 & -.02 & -.01 & -.05 & .04 & .01 \\
\hline $\begin{array}{l}\text { Pozitivno } \\
\text { potkrjepljenje }\end{array}$ & .01 & .03 & -.01 & .01 & -.01 & -.02 \\
\hline $\begin{array}{l}\text { Proaktivno } \\
\text { ponašanje }\end{array}$ & -.04 & -.04 & .00 & .07 & -.02 & .00 \\
\hline Permisivnost & .08 & $.16^{*}$ & .08 & $.18^{*}$ & .06 & -.02 \\
\hline Hostilnost & -.03 & -.10 & -.04 & -.05 & -.08 & .03 \\
\hline Fizička kontrola & -.02 & .06 & .02 & .02 & .05 & -.02 \\
\hline $\mathrm{R}\left(\mathrm{R}^{2}\right)$ & $.82(.67)$ & $.77(.59)$ & $.82(.67)$ & $.78(.60)$ & $.86(.74)$ & $.86(.74)$ \\
\hline$\Delta \mathbf{R}^{2}$ & .01 & .03 & .01 & .02 & .01 & .00 \\
\hline$F(d f)$ & $\begin{array}{c}36.97^{*} \\
(10.183)\end{array}$ & $\begin{array}{c}25.93 * \\
(10.183)\end{array}$ & $\begin{array}{c}36.47 * \\
(10.183)\end{array}$ & $\begin{array}{c}27.75^{*} \\
(10.183)\end{array}$ & $\begin{array}{c}52.39 * \\
(10.183)\end{array}$ & $\begin{array}{c}51.34 * \\
(10.183)\end{array}$ \\
\hline
\end{tabular}

$* \mathrm{p}<.05$ 
U Tablici 9 prikazani su rezultati hijerarhijskih regresijskih analiza s razvojnim obilježjima kao kriterijima te roditeljskim ponašanjima i dječjim temperamentom kao prediktorskim varijablama. U prvom bloku uvedene su varijable temperamenta koje su značajno pridonijele objašnjenju razvojnih ishoda svih mjerenih područja. Pritom je samostalni značajni prediktorski potencijal imala socijabilnost za sva razvojna područja, a ostale su se dimenzije temperamenta pokazale značajnima za pojedina područja razvoja. Tako je emocionalnost značajan negativni prediktor razvoja govora, samostalnosti, socioemocionalnih vještina, odnosno pozitivan prediktor za razvojne poteškoće. Aktivnost je značajan prediktor samo razvoju fine motorike, a impulzivnost je, kao dimenzija temperamenta, značajno objasnila dio varijance razvoja govora, kognitivnih sposobnosti i razvojnih poteškoća. Uvođenjem roditeljskih varijabli, u drugom koraku analize, nije došlo do značajnih promjena koeficijenata multiple korelacije, što upućuje na zaključak da roditeljska ponašanja ne objašnjavaju individualne razlike u razvojnim ishodima povrh temperamenta. Ukupno su odabrani prediktori objasnili visokih $59 \%$ do 74 \% varijance kriterija, što se može gotovo u cijelosti pripisati dimenzijama temperamenta djeteta koje su procijenili roditelji.

\section{RASPRAVA}

Glavni problem istraživanja bio je ispitati povezanost dimenzija temperamenta, roditeljskog ponašanja i razvojnih značajki djeteta te utvrditi pridonose li dimenzije roditeljskog ponašanja i temperamenta djeteta razvojnim značajkama djeteta. Prije analize glavnog problema željelo se ispitati postojanje povezanosti sociodemografskih obilježja roditelja i njihovih procjena roditeljskog ponašanja te postojanje razlika u roditeljskim ponašanjima, roditeljskoj procjeni dječjeg temperamenta i razvojnih značajki s obzirom na spol djeteta.

Rezultati usporedbe procjena roditelja o temperamentalnim obilježjima dječaka i djevojčica nisu pokazali značajne razlike s obzirom na spol djeteta. Ovi rezultati odstupaju od očekivanja temeljenima na dobro dokumentiranim ranim spolnim razlikama u temperamentu na koja upućuju rezultati ranijih istraživanja. Naime, metaanaliza spolnih razlika u ranom temperamentu (Else-Quest i sur., 2006) jasno je uputila na spolne razlike koje su najočitije u dimenzijama kontrole s naporom, surgencije i aktivnosti. Rezultati ovoga istraživanja nisu potvrdili te razlike, što je vjerojatno posljedica različitih metodoloških aspekata istraživanja. Naime, u ovom su istraživanju djetetov temperament procjenjivali jedino roditelji i to mrežno procjenom dimenzija temperamenta prema modelu EASI. Osim razlike u teorijskom modelu, valja istaknuti da je upravo način roditeljske procjene vrlo važan u procjenjivanju djetetovih obilježja. Stoga bi u sljedećim istraživanjima trebalo uključiti i procjene odgojitelja ili drugih stručnih osoba, što sugeriraju i drugi autori (Sindik i Basta-Frljić, 2008; Tatalović Vorkapić i Lončarić, 2015). 
Rezultati analize roditeljskih ponašanja s obzirom na spol djeteta pokazali su kako se roditeljska ponašanja ne razlikuju značajno kada je riječ o djevojčicama i dječacima. Dakle, roditelji su procijenili i pozitivne (toplina, proaktivno roditeljsko ponašanje, pozitivno potkrjepljenje) i negativne (fizička kontrola, permisivnost, hostilnost) aspekte roditeljskih ponašanja jednakima bez obzira na to je li riječ o dječaku ili djevojčici. Nadalje, roditeljske usporedbe u ponašanjima uputile su na zaključak da se majke i očevi razlikuju u toplini i proaktivnom roditeljskom ponašanju, koje su višima procijenile majke u odnosu na očeve, odnosno u permisivnosti, koja je procijenjena višom u očeva. U ostalim trima dimenzijama roditeljskog ponašanja nisu utvrđene značajne razlike između majki i očeva. Rezultat koji upućuje na to da su majke u odnosu na očeve toplije i sklonije proaktivnom roditeljskom ponašanju u skladu je s očekivanjima i rezultatima ranijih istraživanja. Tako je $\mathrm{u}$ istraživanju Maglice i sur. (2020) pokazano kako su majke u odnosu na očeve empatičnije prema djeci predškolske dobi i imaju više razumijevanja, što donekle odgovara dimenziji roditeljske topline. Kada je riječ o permisivnosti, moguće je da majke, s obzirom na to da provode znatno više vremena u interakciji s djecom predškolske dobi u odnosu na očeve (Altenburger i sur., 2018), više inzistiraju na poštivanju pravila i manje su sklone permisivnom pristupu. Moguće je i to da su majke u većini obitelji na određeni način te koje preuzimaju ulogu postavljanja granica pa se posljedično percipiraju manje permisivnima. Očevi su tijekom predškolske dobi obično više uključeni u aktivnosti koje se odnose na igru i bavljenje različitim aktivnostima pa je moguće i prostor za permisivnost prema postavljanju i održavanju granica i pravila ponašanja manji kod očeva nego kod majki.

Treba napomenuti da rezultati nisu uputili na povezanost između dobi ili razine obrazovanja roditelja te bilo koje od šest dimenzija roditeljskog ponašanja. Iako se moglo očekivati da će mlađi roditelji pokazivati višu razinu permisivnosti zbog nedostatka vještina i više razine stresa (Kušević, 2009) ili da će roditelji višeg stupnja obrazovanja pokazivati višu razinu proaktivnog roditeljskog ponašanja zbog veće motiviranosti u pogledu razvoja pedagoške kompetencije (Kesselring i sur., 2012, prema Šimić i Ljubetić, 2018), dobiveni rezultati možda su posljedica relativno male varijabilnosti u objema navedenim sociodemografskim varijablama.

Suprotno očekivanjima, rezultati povezanosti između dimenzija temperamenta i roditeljskih ponašanja uputili su na značajnu povezanost dimenzije aktivnosti te dviju dimenzija roditeljskog ponašanja - hostilnosti i fizičke kontrole. Drugim riječima, roditelji koji su procijenili višu razinu aktivnosti djeteta ujedno se češće koriste fizičkom kontrolom i pokazuju hostilnost prema djetetu. U svim ostalim kombinacijama nije utvrđena značajna povezanost između procijenjenog temperamenta djeteta i roditeljskih postupanja. Dobiveni rezultat o povezanosti aktivnosti i hostilnosti te fizičke kontrole ne iznenađuje s obzirom na to da roditelji koji su procijenili visoku razinu aktivnosti djeteta (ne može sjediti, voli trčati, nemirno je, 
ima stalnu potrebu za kretanjem) vjerojatno smatraju da je fizička kontrola odgovarajući postupak u pokušaju reguliranja djetetova ponašanja. Moguće je i to da takva visoka aktivnost kod roditelja izaziva stres na koji reagiraju hostilnošću u nemogućnosti odabira primjerenije reakcije. Izostanak povezanosti između ostalih dimenzija temperamenta i roditeljskih ponašanja nije sasvim u skladu s modelima roditeljstva koji predviđaju da temperament djeteta u određenoj mjeri oblikuje roditeljska ponašanja. Primjerice, prema modelu determinanti roditeljskog ponašanja (Belsky, 1984), pored osobina roditelja, i temperamentalne značajke djeteta predstavljaju značajnu odrednicu roditeljskog ponašanja, slično kao i prema integrativnom modelu roditeljstva koji predlažu Obradović i Čudina Obradović (2003). Ipak, dosadašnjim se istraživanjima rijetko ispitivala neposredna povezanost djetetova temperamenta i roditeljskih postupanja, a velik broj istraživanja u području roditeljstva usmjeravao se na proučavanje posljedica roditeljskog ponašanja na prilagodbu djeteta, a manji se broj istraživanja bavio pitanjem što uzrokuje roditeljsko ponašanje (Macuka, 2010). U pogledu temperamenta bitno je napomenuti kako je većina dosadašnjih istraživanja temperamenta obuhvaćala djecu rane i školske dobi za razliku od predškolske djece (Sindik i Basta-Frljić, 2008). Razlog nekonzistentnosti dobivenih rezultata može proizlaziti i iz metaemocija procjenjivača, u ovom slučaju roditelja, objašnjava Brajša-Žganec (2002, prema Sindik i Basta-Frljić, 2008), no također je moguće da su sudionici odabirali društveno poželjne odgovore. Ipak, djetetovo ponašanje koje se procjenjuje u samo jednom situacijskom sklopu (kod kuće) ne mora dati realan uvid u djetetov ponašajni stil. Štoviše, Tatalović Vorkapić i Lončarić (2015) naglašavaju da je prilikom procjenjivanja djetetova temperamenta prikladnije uzeti procjene odgojitelja djece predškolske dobi za razliku od procjena roditelja.

Za procjenu povezanosti temperamentalnih značajki i razvojnih ishoda djece rezultati ovog istraživanja pokazali su statistički značajnu povezanost između većine varijabla. Iz tablice interkorelacija (Tablica 8) vidljivo je da su sve djetetove razvojne značajke, izuzev kognitivnih sposobnosti (govor, fina motorika, razina samostalnosti, kognitivne i socioemocionalne sposobnosti), statistički značajno pozitivno povezane s dimenzijama socijabilnosti i aktivnosti, a iste su te razvojne značajke statistički značajno negativno povezane s dimenzijama emocionalnosti i impulzivnosti. Pored toga, određene internalizirane i eksternalizirane poteškoće pokazale su se statistički značajno pozitivno povezane s dimenzijama emocionalnosti i impulzivnosti, a s preostalim su se dvjema dimenzijama temperamenta pokazale statistički značajno negativno povezane. Macuka (2008) naglašava kako se eksternalizirani poremećaji manifestiraju kao nedovoljno kontrolirana ponašanja koja su usmjerena prema van, a internalizirani se poremećaji manifestiraju kao unutarnje reakcije (strah, panika, anksioznost i sl.). Slično rezultatima ovoga istraživanja, istraživanje koje su proveli Sindik i Basta-Frljić (2007) pokazuje 
povezanost razvojnih problema s trima dimenzijama temperamenta: impulzivnosti, emocionalnosti i aktivnosti.

Suprotno očekivanjima, rezultati hijerarhijskih regresijskih analiza (Tablica 9) pokazali su da roditeljska ponašanja značajno ne pridonose objašnjenju individualnih razlika u razvojnim obilježjima djece povrh dimenzija temperamenta. Drugim riječima, uz kontrolu dimenzija temperamenta djeteta, roditeljskim se ponašanjima ne mogu objasniti individualne razlike ni u jednom razvojnom području koje je uključeno u ovo istraživanje. Iako nisu očekivani, rezultate treba sagledati u kontekstu metodoloških ograničenja istraživanja s obzirom na to da su sve procjenjivali isključivo roditelji.

\section{ZAKLJUČAK}

Prije zaključka valja se osvrnuti na nedostatke provedenog istraživanja koji se odnose na veličinu i strukturu uzorka, odnosno činjenicu da je riječ o pristranom i razmjerno malom uzorku te da su sudjelovale uglavnom majke. Nadalje, sve su varijable rezultat samoprocjena i procjena roditelja koji su jedini procjenjivali i dimenzije djetetova temperamenta i djetetove razvojne ishode, ali i vlastita roditeljska ponašanja. Svakako se preporučuje u budućim istraživanjima uključiti procjene drugih odraslih osoba (stručnjaka, odgojitelja) kako bi te procjene bile valjanije. Uključivanje odgojitelja u procjene djece bilo bi korisno i s obzirom na to što djeca manifestiraju različita ponašanja u različitim situacijskim uvjetima te bi korištenje više izvora procjene dalo potpuniju sliku o djetetovu ponašanju. Konačno, valja naglasiti i donekle nižu pouzdanost pojedinih podljestvica, posebno podljestvice aktivnosti u Upitniku temperamenta te podljestvice topline, pozitivnog potkrjepljenja, proaktivnog ponašanja i hostilnosti iz Multidimenzijskog upitnika roditeljstva. Ipak, unatoč donekle nižim koeficijentima pouzdanosti podljestvica rezultati su uputili na zadovoljavajuće pristajanje podataka šest-faktorskom modelu te je stoga taj model $i$ korišten $u$ analizi podataka.

Unatoč navedenim nedostatcima rezultati dobiveni ovim istraživanjem potvrđuju povezanost između aktivnosti djeteta te dviju dimenzija roditeljskog ponašanja, hostilnosti i fizičke kontrole, a u ostalim korelacijama nije utvrđena značajna povezanost između pojedinih dimenzija temperamenta i roditeljskog postupanja. Kada se osvrnemo na rezultate procjene temperamentalnih značajki djeteta i razvojnih ishoda, vidljiva je statistički značajna povezanost između većine varijabla, a pokazalo se da roditeljska ponašanja ne pridonose dodatno procjenama razvojnih obilježja djece uz kontrolu temperamenta koji se u ovom istraživanju pokazao glavnom odrednicom razvojnih značajki djece predškolske dobi. Rezultati su uputili na potrebu uvažavanja specifičnosti dječjeg temperamenta pri analiziranju doprinosa različitih roditeljskih ponašanja razvojnim ishodima djece predškolske dobi. 


\section{LITERATURA}

1. Altenburger, L. E., Schoppe-Sullivan, S. J. i Kamp Dush, C. M. (2018). Associations between maternal gatekeeping and fathers' parenting quality. Journal of Child and Family Studies, 27, 2678-2689. DOI: 10.1007/s10826-018-1146-9

2. Bašić, J., Koller Trbović, N. i Žižak, A. (2005). Integralna metoda u radu s predškolskom djecom i njihovim roditeljima - priručnik. Alinea.

3. Baumrind, D. (1967). Child care practices anteceding three patterns of preschool behavior. Genetic Psychology Monographs, 75(1), 43-88.

4. Belsky, J. (1984). The determinants of parenting: A process model. Child Development, 55(1), 83-96. DOI: $10.2307 / 1129836$

5. Berk, L. (2015). Dječja razvojna psihologija. Naklada Slap.

6. Berk, L. (2008). Psihologija cjeloživotnog razvoja. Naklada Slap.

7. Brezinšćak, T. i Roje, M. (2018). Emocionalni razvoj djeteta. U G. Buljan Flander i sur. (ur.), Znanost i umjetnost odgoja. Praktični priručnik o suvremenom odgoju za roditelje i odgajatelje (str. 47-65). Naklada Geromar.

8. Buss, A. H. i Plomin, R. (1975). A temperament theory of personality development. Wiley-Interscience.

9. Buss, A. H. i Plomin, R. (1984). Theory and measurement of EAS. U A. H. Buss i R. Plomin (ur.), Temperament: Early developing personality traits (str. 98-130). Erlbaum.

10. Buljan Flander, G. i Ćorić Špoljar, R. (2018). Roditeljstvo nekad i danas. U G. Buljan Flander i sur. (ur.), Znanost i umjetnost odgoja. Praktični priručnik o suvremenom odgoju za roditelje i odgajatelje (str. 21-31). Naklada Geromar.

11. Else-Quest, N. M., Shibley Hyde, J., Goldsmith, H. i Van Hulle, C. A. (2006). Gender differences in temperament: A meta-analysis. Psychological Bulletin, 132(1), 33-72. DOI: $10.1037 / 0033-2909.132 .1 .33$

12. Gravetter, F. i Wallnau, L. (2014). Essentials of statistics for the behavioral sciences (8th ed.). Wadsworth.

13. Hui, C. H. i Triandis, H. C. (1985). Measurement in cross-cultural psychology: a review and comparison of strategies. Journal of Cross-Cultural Psychology, 16, 131152. DOI:10.1177/0022002185016002001

14. Katz, L. i McClellan, D. (2005). Poticanje razvoja dječje socijalne kompetencije. Educa.

15. Klarin, M. (2006). Razvoj djece u socijalnom kontekstu. Naklada Slap.

16. Kušević, B. (2009). Licencija za roditeljstvo - buduća realnost ili utopijska projekcija?. Pedagogijska istraživanja, 6(1-2), 191-200.

17. Ljubetić, M. (2012). Nosi li dobre roditelje roda?! Profil International.

18. Ljubetić, M. (2011). Filozofija roditeljstva - obiteljsko ili društveno pitanje? Pedagogijska istraživanja, 8(2), 283-293.

19. Ljubetić, M. i Batinica, V. (2015). Odnos kvalitete prošlog odnosa s ocem i nekih značajki rizičnog ponašanja kćeri (pilot-istraživanje). Napredak, 156(3), 253-266.

20. Ljubetić, M., Reić Ercegovac, I. i Draganja, A. (2019). Razlike između odgojitelja i roditelja djece predškolske dobi u procjeni dječjih socio-emocionalnih kompetencija. Odgojno-obrazovne teme, 2(3-4), 185-204. 
21. Macuka, I. (2010). Osobne i kontekstualne odrednice roditeljskog ponašanja. Suvremena psihologija, 13(1), 63-80.

22. Macuka, I. (2008). Uloga dječje percepcije roditeljskoga ponašanja u objašnjenju internaliziranih i eksternaliziranih problema. Društvena istraživanja, 17(6), 1179-1202.

23. Maglica, T., Reić Ercegovac, I. i Ljubetić, M. (2020). Mindful parenting and behavioural problems in preschool children. Hrvatska revija za rehabilitacijska istraživanja, 56(1), 44-57.

24. Mathiesen, S. K. i Tambs, K. (1999). The EAS temperament questionnaire-factor structure, age trends, reliability, and stability in a Norwegian sample. Journal of Child Psychology and Psychiatry, 3, 431-439. DOI:10.1111/1469-7610.00460

25. Obradović, J. i Čudina-Obradović, M. (2003). Potpora roditeljstvu: izazovi i mogućnosti. Revija za socijalnu politiku, 10(1), 45-68.

26. Parent, J. i Forehand, R. (2017). The multidimensional assessment of parenting scale (MAPS): Development and psychometric properties. Journal of Child and Family Studies, 26, 2136-2151. DOI:10.1007/s10826-017-0741-5

27. Parent, J., McKee, L. G., Rough, J. N. i Forehand, R. (2016). The association of parent mindfulness with parenting and youth psychopathology across three developmental stages. Journal of Abnormal Child Psychology, 44, 191-202. DOI: 10.1007/ s10802-015-9978-X

28. Pernar, M. (2010). Roditeljstvo. Medicina Fluminensis, 46(3), 255-260.

29. Reić Ercegovac, I. i Ljubetić, M. (2019). Svjesnost u roditeljstvu majki i očeva djece različite dobi: Validacija hrvatske inačice upitnika. Psihologijske teme, 28(2), 397-418.

30. Rohner, R. P. (1986). New perspectives on family. The warmth dimension: Foundations of parental acceptance-rejection theory. Sage Publications, Inc.

31. Roje, M. i Buljan Flander, G. (2018). Misaoni razvoj. U: G. Buljan Flander i sur. (ur.), Znanost $i$ umjetnost odgoja. Praktični priručnik o suvremenom odgoju za roditelje $i$ odgajatelje (str. 75-89). Naklada Geromar.

32. Rothbart, M. i Derryberry, D. (1981). Development of individual differences in temperament. U M. E. Lamb i A. L. Brown (ur.), Advances in Developmental Psychology, Vol. 1 (pp. 33-86). Earlbaum.

33. Rothbart, M. K. i Putnam, S. (2002). Temperament and socialization. U L. Pulkkinen i A. Caspi (ur.), Paths to successful development: Personality in the life course (str. 19-45). Cambridge University Press.

34. Sindik, J. i Basta-Frljić, R. (2008). Povezanost karakteristika temperamenta i spremnosti djece za školu. Magistra iadertina, 3(1), 147-169.

35. Slunjski, E. (2012). Tragovima dječjih stopa. Profil International.

36. Slunjski, E. (2001). Integrirani predškolski kurikulum: rad djece na projektima. Mali profesor.

37. Starc, B., Čudina-Obradović, M., Letica, M., Profaca, B. i Pleša, A. (2004). Osobine i psihološki uvjeti razvoja djeteta predškolske dobi. Golden marketing - Tehnička knjiga.

38. Šimić, K. i Ljubetić, M. (2018). Razlike među roditeljima u percepciji pedagoške kompetencije. Učenje i nastava, 4(3), 437-458. 
39. Štimac, D. i Božić Knež, I. (2018). Motorički razvoj djeteta u ranoj dobi. U G. Buljan Flander i sur. (ur.), Znanost i umjetnost odgoja. Praktični priručnik o suvremenom odgoju za roditelje i odgajatelje (str. 65-75). Naklada Geromar.

40. Tatalović Vorkapić, S. i Lončarić, D. (2015). Measuring preschool children temperament: Implications for preschool care and education practice. International Journal of Educational Psychology, 4(3), 280-304. DOI:17583/ijep.2015.1483

41. Tatalović Vorkapić, S. i Žagar, J. (2017). Is the evaluation of children's temperament independent from pre-school teachers' personality? The European Proceedings of Social \& Behavioural Sciences, XX (str. 84-96). Pristupljeno: 19. 3. 2020.

42. Van de Vijver, F. i Hambleton, R. K. (1996). Translating tests: Some practical guidelines. European Psychologist, 1(2), 89-99. DOI:10.1027/1016-9040.1.2.8

43. Vasta, R., Haith, M. i Miller, S. (1997). Dječja psihologija. Naklada Slap. 
